\title{
DETERMINANTS OF VOLUNTARY BANK DISCLOSURE: EVIDENCE FROM JAPANESE SHINKIN BANKS
}

\author{
MARK M. SPIEGEL \\ NOBUYOSHI YAMORI
}

\begin{abstract}
CESIFO WORKING PAPER NO. 1135
CATEgORy 6: MONETARy POLICY AND InTERnATIONAL FinANCE
\end{abstract}

FEBRUARY 2004

Presented at Venice Summer Institute, Workshop on Economic Stagnation in Japan July 2003

An electronic version of the paper may be downloaded

- from the SSRN website:

- from the CESifo website:

www.SSRN.com

www.CESifo.de 


\title{
DETERMINANTS OF VOLUNTARY BANK DISCLOSURE: EVIDENCE FROM JAPANESE SHINKIN BANKS
}

\begin{abstract}
Disclosure is widely regarded as a necessary condition for market discipline in a modern financial sector. However, the determinants of disclosure decisions are still unknown, particularly among banks. This paper investigates the determinants of disclosure by Japanese Shinkin banks in 1996 and 1997. This period is unique because disclosure of non-performing loans was voluntary for Shinkin banks at this time. We find that banks with more serious bad loan problems, more leverage, less competitive pressure, and smaller banks were less likely to choose to voluntarily disclose. These results suggest that there may be a role for compulsory disclosure, as weak banks appear to disproportionately avoid voluntary disclosure.
\end{abstract}

JEL Classification: G18, G21.

Keywords: disclosure, Japanese banking, market discipline.

Mark M. Spiegel

Federal Reserve Bank of San Francisco

101 Market Street

San Francisco, CA 94105

U.S.A.

markspiegel@sf.frb.org
Nobuyoshi Yamori

Institute for Advanced Research

Graduate School of Economics

Nagoya University

Japan

This paper was prepared for the CESifo workshop on "Economic Stagnation in Japan" in Venice, Italy. We thank Michael Hutchison and Frank Westermann for organizing an excellent conference. We also thank all of the seminar participants for helpful comments, particularly Rob Dekle, Charles Horioka, Takeo Hoshi, and Takatoshi Ito. Remaining errors are our own. The views expressed in this paper are those of the authors and do not necessarily reflect those of the Board of Governors of the Federal Reserve or the Federal Reserve Bank of San Francisco. 


\section{Introduction}

In the wake of worldwide financial deregulation and technological development in the financial sector, the task of bank supervision and regulation has become even more difficult. In this environment, the benefits of banks voluntarily disclosing their balance sheet positions can be even greater. Self-disclosure provides a channel for enhancing market discipline in the financial sector. Market discipline is expected to play a growing role in bank regulation. It is an important component of the new Basel Banking Committee framework for bank supervision, where it is considered one of the "three pillars" of bank regulation and supervision. ${ }^{1}$

There are a number of papers in the literature that identify empirical examples of market discipline. Flannery and Sorescu (1996), Morgan and Stiroh (2001), and Hancock and Kwast (2001) find a significant positive relationship between U.S. bank bond spreads and indicators of risk to the U.S. banking sector. There are also proposals to require banks to issue subordinated debt to facilitate market discipline [e.g. Calomiris (1999)]. The motivation behind these proposals is that subordinated debt holders will have an incentive to monitor bank positions and spreads on subordinated debt will provide information of potential use to regulators as well as market participants. Recent evidence indicates that private yields reflect information that differs from that possessed by regulators, suggesting that market discipline can enhance the regulatory environment [De Young, et al. (2001), Krainer and Lopez (2002)]. Moreover, the Federal Reserve Board considers market information such as stock prices and interest rate spreads in their bank supervision activities [Federal Reserve Study Group on Disclosure (2000)].

Since firm disclosure enhances market discipline, regulatory authorities attempt to design regulations and accounting standards to enhance the level of disclosure. Nevertheless,

\footnotetext{
${ }^{1}$ Basel Committee on Banking Supervision (1999).
} 
there is a wide disparity in disclosure levels across nations. U.S. disclosure standards are considered high relative to the rest of the world, while disclosure rules in Japan are less stringent.

It is not clear whether private firms would reveal the optimal amount of disclosure without government intervention. Some argue that market forces encourage disclosure, so that depositors and creditors would require higher premia or deny funds to banks revealing less than the optimal level of disclosure. These market forces would then lead banks to optimal disclosure levels. However, there are also reasons to believe that the level of disclosure chosen by banks on their own would fall below the optimal level. As the government is usually a residual claimant on bank assets due to its role as a deposit insurer and a potential lender of last resort, the private sector has less than full incentive to monitor the disclosure levels of banks and to discipline banks for failing to disclose. This would lead us to expect that banks would not voluntarily engage in full disclosure.

Indeed, there appears to be evidence that they do not. For example, Gunther and Moore (2000) investigate the impact of bank exams in the U.S. on the adequacy of the allowance for loan and lease losses. They find that bank exams affect the accuracy of financial information released to the public. In the absence of regulatory exams, banks underestimate the share of nonperforming loans in their balance sheet.

It should be acknowledged that regulations inducing full disclosure would not necessarily be optimal. Banks could respond to disclosure requirements in a number of dimensions, some of which would likely be unintended. For example, a bank wishing to avoid releasing information to a potential rival may call in loans from a problem debtor rather than release information on them publicly. Nevertheless, the general consensus is that the level of disclosure undertaken by Japanese banks is far below the social optimum, although the level of 
disclosure does appear to be improving over time. ${ }^{2}$ For example, Balic, Bradley and Kiguchi (2002) conclude that Japanese "disclosure levels still fall short of the leaders in the Asia Pacific region and the U.S"3 . Moreover, it is widely believed that the degree of disclosure is particularly sub-optimal among Japanese banks. After the burst of the bubble economy, Japanese banks had large holdings of bad loans, but they did not disclose their holdings in a timely manner, even though market participants requested these figures.

While required Japanese disclosure standards were minimal during the 1990s, some banks did respond to requests for disclosure by voluntarily revealing their asset positions. The characteristics of banks that chose to voluntarily disclose this information is of interest, both as an indicator of the incentives faced by Japanese banks and more broadly as an indicator of the factors that lead to voluntary bank disclosure. The latter question is also relevant to bank regulation outside Japan, such as in the United States, where disclosure standards are so strict that there is usually little heterogeneity in disclosure levels across banks.

In this paper, we examine this question by investigating the degree of disclosure among small Japanese credit associations known as Shinkin banks. In this paper, we examine the impact of Shinkin bank characteristics in 1998 on their decisions concerning bad loan disclosure in 1996 and 1997. Our sample is unique because disclosure of non-performing loans by Shinkin banks was voluntary in 1996 and 1997, but became compulsory in 1998. Since individual bank conditions do not change very rapidly, bank conditions in 1998 give us a good indicator of conditions faced by banks in 1996 and 1997, including those banks that decided not to disclose their non-performing loans.

\footnotetext{
${ }^{2}$ Singleton and Globerman (2002) find that voluntary disclosure by Japanese firms has increased significantly.

${ }^{3}$ Yamori and Baba (2001) survey the international literature on disclosure standards.
} 
Using this data, we examine a number of hypotheses concerning the determinants of disclosure decision. Our first hypothesis is that larger Shinkin banks would be more likely to voluntarily disclose. Larger Shinkin banks usually operate in more sophisticated financial environments with depositors that are more adamant about demanding balance sheet information. There may also be economies of scale in the calculation of financial information. Finally, there are regulatory reasons for larger banks to disclose more readily; the National Association of Shinkin Banks (NASB) recommended, but did not require, disclosure by Shinkin banks with deposits exceeding 100 billion yen.

Our second hypothesis is that Shinkin banks would be less likely to voluntarily disclose adverse information. As we discuss below, the relative willingness to disclose adverse information is ambiguous in the literature. Firms may wish to disclose good information to distinguish themselves from their competitors, but they may also feel a need to disclose bad information to avoid exposure to lawsuits. In the case of banks, we believe that the presence of deposit insurance would seem to limit the pressure to voluntarily disclose adverse information, leading us to predict relatively less adverse information disclosure.

Our third hypothesis concerns the impact of financial strength. Traditionally, the Ministry of Finance (MOF) executed the 'convoy system' regarding Japanese banks, ${ }^{4}$ in which stronger banks were limited in their ability to compete against weaker banks. For example, deposit interest rates were limited to levels consistent with profitability by the most inefficient banks. However, by the time of our sample (March 1996 and 1997), the failures of many financial institutions suggest that the MOF had at least partially abandoned the convoy system. ${ }^{5}$

\footnotetext{
${ }^{4}$ See Spiegel (1999) for details of Japanese convoy system.

${ }^{5}$ Spiegel and Yamori (2003) find that the convoy system deteriorated over this period.
} 
Without the convoy system, a bank could benefit from distinguishing its financial situation from those of its rivals. Our third hypothesis is therefore that institutions with lower leverage levels would be more likely to voluntarily disclose their balance sheet information.

Our final hypothesis concerns market conditions. We would expect a bank that operated in a more competitive market to be more likely to pursue voluntary disclosure for a number of reasons: First, one would expect that a bank in a more competitive market would need to be more responsive to depositor demands for disclosure. Second, one would expect that in a less competitive market, banks would be less likely to voluntarily disclose information that was of potential use to rival banks. ${ }^{6}$ Our final hypothesis is therefore that voluntary disclosure would be more prevalent in less concentrated markets.

Our results demonstrate that banks with more serious bad loan problems are less likely to choose to voluntarily disclose. Second, market forces, as measured by the intensity of local competition, did not measurably affect bank disclosure decisions in 1996, but did in 1997. Finally, we find that larger Shinkin banks were more likely to disclose information, in keeping with the corporate literature on disclosure. These results are robust to the inclusion of variables representing regional differences, including past failures in the region and a complete set of regional dummies.

This paper consists of six sections. Section 2 describes the Japanese Shinkin banks. In section 3, we examine the history of bank disclosure in Japan. Section 4 motivates the hypotheses we study in this paper and discusses our data sources. Section 5 discusses our empirical results. Finally, section 6 concludes.

\footnotetext{
${ }^{6}$ Darrough and Stroughton (1990) provide a theoretical model of this impact of market concentration on voluntary disclosure by firms.
} 


\section{Japanese Shinkin Banks}

Japan's Shinkin banks, commonly known as credit associations, are relatively small financial institutions that are privately held by members living or operating near a bank's headquarters. They concentrate their lending on small and medium enterprises in a given region and can only issue up to 20 percent of their loans to non-members [Hsu (1999)]. However, they accept deposits from both members and the public. In 1996, there were 410 Shinkin banks with average outstanding loans of 171 billion yen. The average size of a Shinkin bank is therefore about an eighth that of a regional bank. On average, they have 21 branches and 372 employees [Kano and Tsutsui (2003)].

Despite the fact that they are small individually, the large number of Shinkin banks outstanding implies that as a group they form an important component of the overall Japanese financial system (see Table 1). As a group, Shinkin banks have more deposits and loans outstanding than either the group of Second Regional or Trust banks. Moreover, because Japanese Shinkin banks are mandated to provide a large share of the financing of small and medium firms who might have exceptional difficulty obtaining credit elsewhere [Fukuyama (1996)], their importance to the financial system may exceed their size.

There may be some concern that since Shinkin banks are privately held and only issue loans to their members, they may deviate from decisions based on profit maximization. However, despite the fact that members elect the CEO of Shinkin banks, they have a lot of autonomy in practice. Moreover, while general evidence on Shinkin banks' deposit sources is unavailable, evidence from individual Shinkin banks that do release their deposit share data indicates that a majority of deposits are obtained from the general public, rather than members. ${ }^{7}$

\footnotetext{
${ }^{7}$ For example, Toyohashi Shinkin, the 60th largest shinkin bank, recently disclosed that only
} 
As such, although we admit that Shinkin banks may have unique characteristics because of their status as mutual organizations, we feel comfortable proceeding under the assumption that Shinkin banks do behave in a similar manner to commercial banks and face market discipline from their depositors.

\section{Disclosure by Japanese financial institutions}

In the 1980s, Japanese banks outperformed U.S. and European banks. However, the downturn in the 1990s deteriorated the financial positions of Japanese banks. Moreover, when defaults did occur, collateral values (primarily backed by land and real estate) were not large enough to cover losses. This led to the current bad loan problems faced by Japanese financial institutions.

Japanese banks were initially very reluctant to disclose their bad loan exposure, and disclosure was initially not required by the MOF. However, the public demand for bad loan disclosures grew as the situation deteriorated. This led to large banks (city banks, long-term credit banks, and trust banks) being forced to disclose the magnitude of 'loans to failed borrowers,' which we label $B A D 1$, and 'loans to borrowers who can not pay within six months of due date,' which we label $B A D 2$, at the end of March 1993. First and second regional banks, which are on average smaller than large banks, were also forced to disclose $B A D 1$, but they were not required to disclose $B A D 2$.

Banks sometimes engaged in "evergreening" of loans, i.e. renegotiating loan interest rates and due dates in order to avoid default. This practice left disclosure of $B A D 1$ and $B A D 2$ poor indicators of a bank's true financial condition. In response, large banks have also been required

29.2 percent of its deposits came from its members, while the remainder came from the general public. 
to disclose the magnitude of 'loans with interest rates lower than Bank of Japan's discount rates,' which we label $B A D 3$, since September1995.

Regional banks were also obligated to begin disclosing BAD2 and BAD3 in March 1996. At that time, large banks also began disclosing 'the amounts of loans to borrowers whom banks supported,' which we label $B A D 4$.

Regulation forcing smaller regional financial institutions to disclose was slower in coming. Initially, the MOF encouraged, but did not force smaller financial institutions, such as Shinkin banks and Credit Unions, to disclose these figures. After the failure of several small financial institutions, however, the public demanded the disclosure of information concerning these small institutions' financial condition as well.

The MOF began releasing figures for problem loans of smaller institutions in September 1995. However, it initially only disclosed aggregate figures. The MOF defended its disclosure policy on the basis of concerns that adverse news about individual small banks might trigger runs. However, this policy was strongly criticized after many banks that reported adequate capital positions eventually failed. This led to a growing consensus that transparency in the Japanese financial sector would facilitate the revitalization of the sector.

Because of this external pressure, the National Association of Shinkin Banks (NASB) recommended that the Shinkin banks holding deposits equal to or larger than 100 billion yen disclose their $B A D 1$ positions at the end of March 1996 and that all Shinkin banks disclose their BADl positions at the end of March 1997. However, as we demonstrate below, some Shinkin that fell within this criterion did not disclose their bad loan figures at the end of March 1996. Indeed, a few did not even disclose their bad loan figures by the end of March 1997. In March of 1998, the NASB directed all Shinkin banks to disclose their BAD1, BAD2, BAD3, and BAD4 
positions. It follows that the disclosure of balance sheet positions was "voluntary" for Shinkin banks only in 1996 and 1997 (see Table 2).

Because of the limited disclosure discretion faced by banks in the United States, evidence on voluntary bank disclosure among U.S. banks is limited. However, there is a large literature on voluntary disclosure across U.S. corporations. Skinner $(1994,1997)$ posits that managers choose voluntary disclosure to limit exposure to stockholder litigation. Skinner (1994) finds that managers voluntarily disclose adverse earnings news "early," or before the mandated release date. Skinner (1997) also finds that early voluntary disclosure lowers expected legal costs. These results suggest that managers voluntarily disclose bad news more than good news.

Other research investigates whether voluntary disclosure reduces the cost of capital, as enhanced disclosure reduces information asymmetries. Botosan (1997) finds that greater disclosure is associated with a lower cost of equity capital for firms with low analyst followings. Information asymmetries would be greatest among these firms. Lang and Lundholm (2000) find that firms increase their disclosure activity prior to an equity offering announcement. ${ }^{8}$ These results suggest that firms disclose favorable information to distinguish themselves from less successful firms.

Concerning the disclosure decisions of Japanese corporations, Cooke [(1991), (1992), (1996)] uses annual reports of Japanese corporations to measure the degree of voluntary disclosure. Cooke finds that size is the most important determinant of voluntary disclosure by Japanese firms. Singleton and Globerman (2002) also find that larger Japanese corporations tend to disclose more information.

\footnotetext{
${ }^{8}$ Lang and Lundholm also find that firms that substantially increase their disclosure activity before the offering suffer much larger price declines at the announcement of their intent to issue equity. They interpret this fact as suggesting these firms use voluntary disclosure to "hype the stock."
} 
In addition to size, Cooke finds that firm voluntary disclosure decisions are affected by their equity listing characteristics, including whether and where a firm is listed (domestically or internationally). He also finds that the degree of voluntary disclosure is affected by industry type, distinguishing between manufacturing and other industries, and by leverage.

Cooke (1996) examines the effect of Keiretsu membership on corporate disclosure. Within the Keiretsu, information may be more widely shared. As a result, a firm in a Keiretsu may face less severe information asymmetry difficulties, as it primarily obtains its financing from its Keiretsu main bank partner. This would give firms within a Keiretsu less motivation to voluntarily disclose. However, after controlling for size, stock market listing status, leverage, and industry type, Cooke finds no evidence supporting the hypothesis that Keiretsu firms disclose less information than other firms.

\section{Hypotheses Concerning Disclosure levels}

In this section, we elaborate on the hypotheses we test in our study. As our sample consists of only Shinkin banks, there is no issue of listing status or industry type. Shinkin banks are all unlisted closed membership cooperatives. ${ }^{9}$ Also, due to regulatory constraints, the basic activity of Shinkin banks are all identical. That is, they collect deposits from their member firms and local depositors and lend primarily to member firms.

\footnotetext{
${ }^{9}$ Because Shinkin banks are unlisted, a number of the potential considerations for voluntary disclosure raised in the literature may not be relevant. For example, Healy and Palepu (2001) suggest that disclosure may reduce transactions costs in capital markets by lowering information asymmetries, affect corporate control contests, circumvent inside trade regulation when managers exercise stock options, or signal management talent. Some of these considerations may be irrelevant for unlisted Shinkin banks, while others may manifest themselves in different ways than they would under listed firms.
} 


\subsection{Size}

We expect size to have a positive effect on a firm's disclosure activity for a number of reasons: First, larger firms need to raise capital in the market more frequently and are under greater pressure from shareholders and market analysts for increased disclosure. While Shinkin banks raise little capital in the market, larger Shinkin banks may face greater disclosure pressure from their depositors because they usually operate in more financially-sophisticated environments than smaller Shinkin banks. Customers (both depositors and borrowers) of larger Shinkin banks are more often approached by commercial bank competitors, such as city banks and regional banks. In contrast, small Shinkin banks usually enjoy relatively isolated long-term relationships with their member firms, and are not as exposed to market pressures. For example, the largest Shinkin bank in Japan, Jonan Shinkin bank, is located in Tokyo, the second largest Shinkin bank, Okazaki Shinkin bank, is located in Aichi, and the third largest Shinkin bank, Kyoto-Chuo Shinkin banks, is located in Kyoto. These are all major urban areas with sophisticated financial environments.

It has also been suggested that voluntary disclosure would be positively related to bank size due to economies of scale in the calculation of financial information. For example, Kyobashi Shinkin bank employed only 23 managers and workers as of March 1998. However, we doubt that this argument would apply to Shinkin banks for two reasons. First, the bad loan amount figures we consider should be relatively easy for banks to calculate. Moreover, as the MOF has reported aggregate bad loan figures for Shinkin banks since 1995, they must have received the disaggregated number from all of the Shinkin banks, including the smaller ones. ${ }^{10}$

Finally, there may be regulatory reasons for larger banks to be more likely to voluntarily

\footnotetext{
${ }^{10}$ Chen et al. (2002) argue that disclosure costs are unimportant determinants of voluntary balance sheet disclosure decisions.
} 
disclose. The National Association of Shinkin Banks recommended, but did not require, disclosure by Shinkin banks with deposits exceeding 100 billion yen. Therefore, larger Shinkin banks were under more pressure from the NASB. On the other hand, bank regulation may induce a negative relationship between size and disclosure if larger Shinkin banks are considered too-big-to-fail. However, we doubt this possibility as several banks that were larger than the largest Shinkin banks had failed by the time of our sample [Spiegel and Yamori (2003)].

\subsection{Leverage}

Leverage has also been identified as an important determinant of voluntary disclosure. Firms with higher leverage ratios will incur higher monitoring costs, which can be reduced through disclosure [e.g. Cooke (1996)]. In addition, leverage levels affect depositors' interpretation of the severity of bad loan difficulties. Disclosure of bad loan levels may be positive news if they indicate that management intends to address a bank's bad loan problem. This would of course depend on a bank's capacity to address its difficulties, which would be greater at less leveraged banks, holding all else equal. This may leave managers of less leveraged banks more willing to disclose information on bad loans.

\subsection{Adverse News}

Whether disclosure revealed good or bad news concerning the bank's underlying financial position is obviously also relevant. As discussed above, however, the literature is mixed as to whether firms would be more willing to disclose good or bad information.

Skinner (1994), among others, argued that managers had greater incentives to disclose adverse news due to the expected legal costs from failing to reveal such news, and to the 
potential enhancement of reputations from bad news disclosure. Darrough and Stroughton (1990) argue that managers are more likely to disclose bad news for entry deterrence reasons. Teoh and Hwang (1991) argue that the disclosure of adverse news reveals that a firm can handle the release of such news, and therefore serves as a positive signal of firm quality.

On the other hand, many studies predict that managers would be more willing to disclose good news in order to distinguish their firms from their competitors. For example, Lev and Panman (1990), documented that managers disclose good news forecasts more often than bad news forecasts. Scott (1994), examines Canadian firms' voluntary disclosure of defined benefit pension plan information and also finds that good news is more likely to be disclosed. Verrecchia (1983) finds that more favorable news is more likely to be disclosed, after controlling for disclosure costs.

Usually, one would have difficulty calculating the impact of news quality on the disclosure decision, as conditions faced by banks deciding not to disclose would be unobservable. However, in the case of our sample, all Shinkin banks have faced compulsory disclosure in March 1998. Although there will be some disparities, we believe that the disclosure figures in March 1998 are good predictors of conditions that were not disclosed in 1996 and 1997.

We test this conjecture by looking at the correlation among banks that did choose to disclose during the voluntary periods with their figures in 1998. The correlation coefficient between BAD1 in March 1996 and that in March 1998 is 0.88 for Shinkin banks that disclosed both figures and the correlation coefficient between BADI in March 1997 and March 1998 is 0.94. These high correlation coefficients would appear to confirm our conjecture. 


\subsection{Market Structure}

Shinkin Banks generally operate within a prefecture or smaller region where their headquarters are located. Although these banks specialize in small-size business lending, they do face competition from the rest of the banking industry within their area. It is well known that the level of this competition varies greatly across the nation [Kano and Tsutui (2003)].

We would expect a bank that operated in a more competitive market to be more likely to pursue voluntary disclosure for a number of reasons: First, a bank in a more competitive market would be likely to need to be more responsive to depositor demands for disclosure. Second, one would expect that in a less competitive market, banks would be less likely to voluntarily disclose information that was of potential use to rival banks. ${ }^{11}$

\subsection{Data}

Our dependent variable is binary, representing the discrete disclosure decision of a Shinkin bank concerning the relevant bad loan measure. Our data source is Financial Statements of Shinkin Banks (FSSB) which is published annually by the Kinyu Tosyo Consultant Sha. As this is the only available data source regarding Shinkin banks, if the relevant figures are not reported here, then we assume that the figures were not disclosed. ${ }^{12}$

\footnotetext{
${ }^{11}$ Chen et al. (2002) finds that investors demand greater disclosure when reported losses are higher. In response, managers disclose more when reported losses are large. However, as profits also increase a bank's ability to write off its bad loans, its net impact on willingness to disclose is ambiguous.

To examine the impact of profitability, we added the natural log of business profits (Gyomu-rieki) as of March 1998 in our first stage estimation as a proxy for expected future performance. The variable was insignificant. The results with profits included are available from the authors upon request.

${ }^{12}$ A footnote in the FSSB notes that 18 Shinkin banks claimed that their figures were not available at the FSSB's publication deadline for the March-1996 version, but that they would be disclosed later. However, this claim appears to be dubious, as the publication deadline occurred after the June members' meeting, for which financial statements would have to calculated and approved by auditors. We therefore treat these 18 banks as failing to disclose. Information is unavailable as to whether or not they did eventually disclose their positions that year. We checked the robustness of our results below by re-running our
} 
The level of Shinkin bank disclosure in our sample is summarized in Table 3. There were 416 Shinkin Banks at the end of March 1996, and 407 at the end of March 1997. At the end of March 1996, 305 of the 416 Shinkin banks disclosed BAD1. No banks disclosed BAD2 or $B A D 3$. We use a qualitative variable, $D I S C 96$ as our dependent variable for the March 1996 sample. DISC96 takes unit value if the Shinkin bank disclosed BADI in March 1996 and zero value otherwise.

For March 1997, only 33 Shinkin banks, or 8 percent of the industry, pursued no voluntary disclosure. 139 out of the 407 Shinkin Banks disclosed BAD1, BAD2, and BAD3. While this represents an increase in disclosure levels, it still falls below the rest of the financial sector. Large banks had all disclosed $B A D 1, B A D 2$, and $B A D 3$ since September 1995, while regional banks had disclosed $B A D 1, B A D 2$, and $B A D 3$ since March 1996. For our March 1997 sample, we use an ordered-dummy variable, DISC97, to indicate disclosure intensity. DISC97 takes value zero if a Shinkin bank did not disclose $B A D 1$, takes value one if it disclosed only $B A D 1$, and takes value two if it disclosed both $B A D 1$ and $B A D 2$. Similarly, it takes value three if it disclosed $B A D 1, B A D 2$, and $B A D 3 .{ }^{13}$

Table 3 also displays the geographic distribution of Shinkin disclosure. It can be seen that the magnitude of disclosure by Shinkin banks is asymmetric by region. For example, $94 \%$ of Shinkin banks in Kanto (excluding Tokyo) disclosed BADI at the end of March 1996, while only $46 \%$ of Shinkin banks in Tohoku disclosed BADl in that year. This suggests that regional factors also affect the disclosure decision of Shinkin banks. We control for regional disparities in our robustness checks below.

specification with these 18 Shinkin banks excluded from our sample.

${ }^{13}$ Scott (1994) uses a similar ordered-dummy variable method to indicate disclosure levels. In his study, firms can disclose both pension costs and interest assumptions, only pension costs, or neither. 
Concerning the independent variables, we use assets as of March 1998 as a proxy for size (LASSET). We use the capital ratio as of March 1998 as a proxy of bank leverage (CAPRATIO). We use two measures of the severity of bad loan news contained in the disclosure. HATANRATIO is defined as the ratio of BADI to total loans on March 1998. FURYORATIO is defined that the ratio of $B A D 2$ and $B A D 3$ to total loans on March $1998^{14}$.

We also use two measures of market competitiveness. LGDPBRANCH96 is defined as the log of Gross Prefectural Product (for fiscal year 1995, ending at March 1996) divided by total bank branches and Shinkin banks in March 1996. LGDPBRANCH97 is defined in the same manner and is used for the 1997 disclosure decision estimation. A low value of LGDPBRANCH would imply greater competition in that prefecture. The coefficient on LGDPBRANCH is therefore expected to be negative, as competition would induce more disclosure.

\section{Results}

\subsection{Results for Failed Banks}

Before formally investigating the determinants of Shinkin bank disclosure, we first check the disclosure patterns of the subset of Shinkin banks that failed after the end of March 1997. There was one Shinkin bank failure in 1999, seven in 2000, six in 2001, and 13 in 2002. Disclosure decisions for these failed banks are compared to the rest of the sample in Table 4 . The 27 failed Shinkin banks chose disclosure less frequently than the rest of the sample. Only 50 percent of Shinkin banks that failed between 1998 and 2001 disclosed BAD1 in March 1996, while 75 percent of the surviving Shinkin banks reported $B A D 1$ in that year.

\footnotetext{
${ }^{14}$ We do not anticipate any causality problems with these variables. Bank bad loan problems had been growing since the late 1980s, while Shinkin banks were not required to disclose their bad loan amounts before the mid-1990s. See Core (2001) for further discussion.
} 
It is also interesting to compare Shinkin banks that failed during 1998 to 2001 with those that failed in 2002. The former group, for whom failure was apparently more imminent in March 1997, was more reluctant to disclose bad loan information than the latter group. This finding is consistent with the hypothesis that banks with solvency problems and adverse news disclosed less and that the magnitude of their difficulties affected their disclosure decision.

\subsection{Disclosure Decisions in March 1996}

As banks that did disclose in 1996 only disclosed $B A D 1$, our dependent variable is binary. We therefore report the results of both OLS and PROBIT estimation for disclosure decisions in that year. Missing data reduced our sample size from 416 banks to 387 banks. ${ }^{15}$

Our results for 1996 are shown in Table 5. The results for both OLS and probit estimation are essentially the same. First, our size variable, LASSET, is positive and significant as predicted and consistent with earlier studies.

Recall that the NASB recommended in this year that Shinkin banks holding larger than 100 billion yen deposits disclose their values of $B A D 1$. To investigate whether this was a factor in the more frequent disclosure by larger Shinkin banks, we split the sample into two subsamples based on whether deposit amounts in March 1998 were larger or smaller than 100 billion yen. Out of the 245 Shinkin banks exceeding this deposit level in 1998, only 14 did not disclose their values of $B A D 1$ in March 1996. In contrast, out of the 142 Shinkin banks with less than 100 billion yen in assets, 65 did not disclose $B A D 1$. Therefore, we would conclude that the NASB's recommendation was a factor in the greater amount of disclosure among larger Shinkin banks.

\footnotetext{
${ }^{15}$ Financial statements as of March 1998 for 29 Shinkin banks were not available because of mergers or failures.
} 
The estimated coefficient on our leverage measure, CAPRATIO, is positive but insignificant, implying that leverage was not a very important factor in 1996 disclosure choices.

Turning to our bad loan measures, the estimated coefficient for HATANRATIO is significantly negative at the 5 percent level for both specifications. This suggests that Shinkin banks that held more bad loans were less likely to disclose BAD1 in March 1996. This implies that Shinkin banks were more likely to withhold bad information.

The estimated coefficient for LGDPBRANCH96 is not significant and is unexpectedly positive. This suggests that disparities in market competition did not influence disclosure decisions in 1996.

\subsection{Disclosure Decisions in March 1997}

As $D I S C 97$ is also a qualitative dependent variable, we again report the results of both OLS and ordered probit estimation. Our specification now also includes the FURYORATIO variable. As shown in Table 3, most Shinkin banks disclosed BAD1 for March 1997. Therefore, HATANRATIO was disclosed for most Shinkin banks, while FURYORATIO was still undisclosed for most banks.

The results are shown in Table 5. The coefficient for LASSET is positive for both the OLS and ordered probit estimations. These results suggest that size was still an important determinant of Shinkin banks' disclosure decisions in 1997.

The coefficient on our leverage variable, CAPRATIO, is now significant. This is quite distinct from our 1996 results and appears to be attributable to the decline in Japanese financial conditions between 1996 and 1997. With this decline in financial conditions, the value to sound banks of distinguishing themselves from the rest of the industry was increased. 
Both HATANRATIO and FURYORATIO take their expected negative coefficients, as adverse news is less likely to be disclosed. However, the HATANRATIO coefficient is insignificant in both models, while the coefficient for FURYORATIO is highly significant in both models. This disparity appears to be attributable to the fact that by 1997 there was little variability across Shinkin banks in the disclosure of $B A D 1$, as almost all banks disclosed this figure.

The coefficient for $L G D P B R A N C H 97$ is now significantly negative at around 5 percent. This suggests that competition promotes bank disclosures, as predicted.

To check our robustness, we considered an alternative indicator of disclosure in 1997. We specify our dependent variable as a binary variable that takes value zero if there was no disclosure or if only $B A D 1$ was disclosed, and value one otherwise. Under this specification, 238 Shinkin banks in the sample are given value zero, and 144 Shinkin banks are given value 1 . The results are shown in Table 5. The size variable, LASSET, is now insignificant, but the remaining results are all the same. The coefficients on CAPRATIO, FURYORATIO, and LGDPBRANCH97 all enter significantly with their predicted signs. We therefore conclude that our results are fairly robust to using a binary dependent variable for the 1997 sample.

\subsection{Regional differences}

Kano and Tsutsui (2003) find that Shinkin bank markets are segmented by region. There are also a number of reasons to expect that Shinkin bank disclosure decisions may differ across regions. Shinkin banks in regions in which failures took place may find themselves under greater pressure from depositors to disclose. There are also regional disparities in economic 
conditions. ${ }^{16}$ As such, one would want to condition on regional differences to evaluate the robustness of the results above.

We first examine the impact of regional failure histories. Prior to March 1997, there were only two Shinkin failures; Toyo Shinkin in Osaka in 1992 and Kamaishi Shinkin in Iwate in 1993. However, local commercial bank failures may also have affected the disclosure pressure faced by Shinkin banks. There were four such bank failures before March 1997; Toho Sogo Bank in Ehime in 1992, Hyogo Bank in Hyogo in 1995, Taiheyo Bank in Tokyo in 1996, and Hanwa Bank in Wakayama in 1996. To accommodate regional differences that may have existed due to these failures, we introduce a Regional Failure indicator into our specification. This indicator takes value one if a Shinkin bank is located in one of the prefectures with failure histories mentioned above (i.e. if the bank is from Ehime, Hyogo, Tokyo, and Wakayama), and zero otherwise.

The results are shown in Table 6. The Regional Failure indicator is universally insignificant and therefore leaves the original results largely intact. In particular, we retain the results that larger banks are more likely to disclose, as are banks in stronger financial positions. The most notable difference in our results is that the intensity of local competition no longer enters significantly, although it still takes on the appropriate negative sign. ${ }^{17}$

\footnotetext{
${ }^{16}$ There may also be regional disparities in regulatory treatment. While Shinkin banks from all regions were formally subject ot the same regulatory restrictions, local regulator discretion may have resulted in heterogeneity in the enforcement of these restrictions.

${ }^{17}$ It may be the case that smaller failures did not have as significant impact on their regions. To investigate this possibility, we also limited our Regional Failure dummy to those regions that had failures whose resolution costs to the Deposit Insurance Corporation exceeded 100 billion yen. These included Tokyo (Cosmo Credit Union, Taiheyo), Hyogo (Hyogo Bank), and Osaka (Kizu Credit Union). Our results with this alternative indicator were essentially the same and are available from the authors on request.
} 
Finally, regional disparities may arise for a number of reasons, not limited to local failure histories. To more broadly entertain fixed regional disparities, we also ran our specification with separate dummies for all regions. We construct 8 regional dummies; (1) HOKATOHO, which includes Hokkaido and Tohoku, (2) KANTO, which includes Tokyo, (3) HOKURIKU, (4)CHUBU, which includes Aichi, (5) KINKI, which includes Osaka and Hyogo, (6) CHUGOKU, (7) SHIKOKU, and (8) KYUSHU. The results are shown in Table 7. Again, our results were largely robust to the inclusion of a full set of regional dummies, exception for the local competition variable. ${ }^{18}$

\section{Conclusion.}

Disclosure is widely regarded as a necessary condition for market discipline in a modern financial sector. However, the determinants of disclosure decisions are still unknown, particularly among banks. To formulate optimal disclosure policy, it is necessary to know what factors affect disclosure decision of banks. In this paper, we investigate the determinants of Shinkin banks' bad loan disclosure for March 1996 and 1997. This period is unique because disclosure was voluntary for Shinkin banks during this time.

We obtain several interesting results. First, banks with more serious bad loan problems were less likely to choose to voluntarily disclose. Second, larger Shinkin banks were more likely disclose information, consistent with the corporate literature on disclosure. Finally, market forces, as measured by the intensity of local competition, did not force banks to disclose more information in March 1996, but did in March 1997. This final result, however, was not robust to the inclusion of regional dummy indicators, leaving it difficult to conclude whether the observed

\footnotetext{
${ }^{18}$ For space considerations, the dummy coefficients were not reported. These are available from the authors upon request. To avoid multicollinearity, we dropped the KANTO dummy. As such, the constant coefficient should be interpreted as representing the $K A N T O$ region.
} 
regional differences were truly attributable to differences in local competition conditions, or to other factors, such as disparities in local failure experiences.

There are several questions for future investigation. First, in this paper, we only investigated the decision to disclose bad loan ratios. Some analysts contend that bad loan disclosure is insufficient to evaluate banks' financial conditions. It is therefore important to examine the determinants of disclosure of other types of bank information. Second, the credibility of the disclosed information is also uncertain. ${ }^{19}$ As Hutchison (1997) pointed out, the MOF several times changed financial disclosure and accounting rules to allow stock losses to be deferred and to delay the effect of real estate price declines on banks' reported capital. The quality of disclosed information could affect bank decisions as to whether or not to disclose. Third, our study demonstrates that weak banks are less likely to voluntarily disclose. There may therefore be a role for compulsory disclosure, as such a requirement may disproportionately fall on weaker banks. It would be interesting to evaluate the impact of such disclosure requirements on bank behavior.

Finally, the impact of disclosure on bank systematic risk is also of interest. Banks' assets are opaque, in the sense that it is hard for outsiders to evaluate bank loan quality due to information asymmetry. Furthermore, banks rely heavily on short-term liabilities. Disclosure by individual banks may trigger market-wide actions by private stakeholders, leading to systemic risk [Federal Reserve System Study Group on Disclosure (2000)]. ${ }^{20}$ Regarding U.S. banks,

\footnotetext{
${ }^{19}$ Although only limited information is available, there is some evidence that Japanese markets did discipline riskier banks (e.g., Genay 1999, Yamori 1999, Bremer and Pettway 2002). Therefore, disclosure may enhance market discipline.

${ }^{20}$ For example, Cordella and Yeyati (1998) construct a theoretical model to study the effect of disclosure on the probability of banking crises. They find that when banks do not control their risk exposure, disclosure may increase the probability of bank failures.
} 
Jordan et al. (2000) found that disclosure was not destabilizing. It would be interesting to examine if this was also the case for Japan. 


\section{References}

Balic, Amra, Nicholas Bradley, and Hiroko Kiguchi, 2002, "Results of Japan Transparency and Disclosure Survey for S\&P/TOPIX 150 Companies," available at S\&P web site (http://standardandpoors.com).

Basel Committee on Banking Supervision, 1999, "New Capital Adequacy Framework," Bank for International Settlement.

Botosan, Christine A., 1997, "Disclosure Level and the Cost of Equity Capital," The Accounting Review 72(3), 323-349.

Bremer, Marc, and Richard H. Pettway, "Information and the Market's Perceptions of Japanese Bank Risk: Regulation, Environment, and Disclosure," Pacific-Basin Finance Journal 10, 119-139.

Calomiris, Charles W., 1999, "Building an Incentive Compatible Safety Net," Journal of Banking and Finance 23(10), 1499-1519.

Cargill, T., M. Hutchison, and T. Ito, 1997, The Political Economy of Japanese Monetary Policy, Cambridge: MIT Press.

Chen, Shuping, Mark L. DeFond, and Chul W. Park, 2002, "Voluntary Disclosure of Balance Sheet Information in Quarterly Earnings Announcements," Journal of Accounting and Economics 33, 229-251.

Cordella, Tito, and Eduardo Levy Yeyati, 1998, "Public Disclosure and Bank Failures," IMF Staff Papers 45(1), 110-131.

Cooke, Terry, E., 1991, "An Assessment of Voluntary Disclosure in the Annual Reports of Japanese Corporations," International Journal of Accounting 26, 174-189.

Cooke, Terry, E., 1992, "The Impact of Size, Stock Market Listing and Industry Type on Disclosure in the Annual Reports of Japanese Listed Corporation," Accounting and Business Research 22, 229-237.

Cooke, Terry E., 1996, "The Influence of the Keiretsu on Japanese Corporate Disclosure," Journal of International Financial Management and Accounting 7(3), 191-214.

Core, John E., 2001, “A Review of the Empirical Disclosure Literature: Discussion,” Journal of Accounting and Economics 31, 441-456.

Darrough, M. H., and N. M. Stoughton, 1990, "Financial Disclosure Policy in an Entry Game," Journal of Accounting and Economics 12, 219-243. 
DeYoung, R., Flannery, M., Lang, M., and Sorescu, S., 2001. “The Information Content of Bank Exam Ratings and Subordinated Debt Prices," Journal of Money, Credit, and Banking, 33, 900-925.

Federal Reserve Study Group on Disclosure, 2000, "Improving Public Disclosure in Banking," Board of Governors of the Federal Reserve System Staff Study 173, 1-35.

Flannery, Mark J. and Sorin M. Sorescu, 1996, "Evidence of Bank Market Discipline in Subordinated Debenture Yields," Journal of Finance 51, 1347-1377.

Fukuyama, Hirofumi, 1996, "Returns to Scale and Efficiency of Credit Associations in Japan: A Nonparametric Approach," Japan and the World Economy, 8, 259-277.

Genay, H., 1999, “Japanese Banks and Market discipline,” Chicago Fed Letter 144, 1-3.

Gunther, Jeffery W., and Robert R. Moore, 2000, "Financial Statements and Reality: Do Troubled Banks Tell All?" Federal Reserve Bank of Dallas Economic and Financial Review, Third Quarter, 30-35.

Hancock, Diana, and Myron L. Kwast, 2001, "Using Subordinated Debt to Monitor Bank Holding Companies: Is It Feasible?,” Journal of Financial Services Research, 20:2/3, 147187.

Healy, Paul M., and Krishna G. Palepu, 2001, "Information Asymmetry, Corporate Disclosure, and the Capital Markets: A review of the Empirical Disclosure Literature," Journal of Accounting and Economics 31, 405-440.

Hsu, Robert C., 1999, "Shinkin Banks," in his The MIT Encyclopedia of the Japanese Economy, Second Edition: the MIT Press, Cambridge MA, 399-400.

Hutchison, Michael, 1997, "Financial Crises and Bank Supervision: New Directions for Japan?" Federal Reserve Bank of San Francisco Economic Letter 97-37.

Jordan, John S., and Joe Peek and Eric Rosengren, 2000, “The Impact of Greater bank Disclosure Amidst a Banking Crisis,” Journal of Financial Intermediation 9, 298-319.

Kano, Masaji, and Yoshiro Tsutui, 2003, "Geographical Segmentation in Japanese Bank Loan Markets," Regional Science and Urban Economics, 33, 157-174.

Kashyap, Anil K., 2002, “Sorting out Japan's Financial Crisis,” Federal Reserve Bank of Chicago Economic Perspectives 2002-4Q, 42-55.

Krainer, John and Jose A. Lopez, 2002, "Incorporating Equity Market Information into Supervisory Monitoring Models," FRBSF Working Paper no. 2001-14. 
Lang, mark H., and Russell J. Lundholm, 2000, "Voluntary Disclosure and Equity Offerings: Reducing Information Asymmetry or Hyping the Stock?” Contemporary Accounting Research 17(4), 623-662.

Lev, B., and S.H. Penman, 1990, "Voluntary Forecast Disclosures, Nondisclosure, and Stock Prices," Journal of Accounting Research 28, 49-76.

Morgan, Donald P. and Kevin J. Stiroh, 2001, "Market Discipline of Banks: The Asset Test," Journal of Financial Services Research 20, 195-208.

Scott, Thomas William, 1994, "Incentives and Disincentives for Financial Disclosure: Voluntary Disclosure of Defined benefit Pension Plan Information by Canadian Firms," The Accounting Review 69(1), 26-43.

Singleton, W.R., and Steven Globerman, 2002, "The Changing Nature of Financial Disclosure in Japan," International Journal of Accounting 37, 95-111.

Skinner, Douglas J., 1994, "Why firms voluntarily disclose bad news," Journal of Accounting Research 32, 38-60.

Skinner, Douglas J., 1997, "Earnings Disclosures and Stockholder Lawsuits," Journal of Accounting and Economics 23, 249-282.

Spiegel, Mark, 1999, "Moral hazard under the Japanese "convoy" banking system," Federal Reserve Bank of San Francisco Economic Review, 3-13.

Spiegel, Mark, and Nobuyoshi Yamori, forthcoming, "The Evolution of Bank Resolution Policies in Japan: Evidence from Market Equity Values," Journal of Financial Research.

Teoh, S.H., and C. Y. Hwang, 1991, "Nondisclosure and Adverse Selection as Signals of Firm Value," Review of Financial Studies 4, 283-313.

Verrecchia, Robert E., "Discretionary Disclosure," Journal of Accounting and Economics 5, 179194.

Yamori, Nobuyoshi, 1999, "Stock Market Reaction to the Bank Liquidation in Japan: A Case for the Informational Effect Hypothesis," Journal of Financial Services Research 15(1), 57-68.

Yamori, Nobuyoshi, and Taiji Baba, 2001, "Japanese Management Views on Overseas Exchange Listings Survey Results," Journal of International Financial Management and Accounting 12-3, pp. 286-316. 
Table 1. Japanese Financial Institutions, March 1996

\begin{tabular}{|l|c|c|c|}
\hline \multicolumn{1}{|c|}{ Bank Type } & $\begin{array}{c}\text { Number of } \\
\text { Banks }\end{array}$ & $\begin{array}{c}\text { Deposits } \\
\text { (billion yen) }\end{array}$ & $\begin{array}{c}\text { Loans } \\
\text { (billion yen) }\end{array}$ \\
\hline City Banks & 10 & 214,406 & 215,236 \\
\hline Regional Banks & 64 & 168,732 & 135,998 \\
\hline $\begin{array}{l}\text { Second } \\
\text { Regional Banks }\end{array}$ & 65 & 61,265 & 53,280 \\
\hline Trust Banks & 33 & 17,146 & 31,584 \\
\hline Shinkin Banks & 410 & 97,732 & 70,201 \\
\hline
\end{tabular}

Source: Economic Statistics Monthly, Bank of Japan 


\section{Table 2. "Bad-loan" Disclosure Requirements Among Japanese Financial Institutions ${ }^{\mathrm{a}}$}

\section{BAD1 \\ BAD2 \\ BAD3 \\ BAD4}

\begin{tabular}{|c|c|c|c|c|}
\hline $\begin{array}{l}\text { Large Banks } \\
\text { (City, long-term } \\
\text { credit, and trust } \\
\text { banks) }\end{array}$ & March 1993 & March 1993 & March $1996^{\mathrm{b}}$ & September $1996^{c}$ \\
\hline Regional Banks & March 1993 & March 1996 & March $1997^{\mathrm{d}}$ & March 1997 \\
\hline $\begin{array}{l}\text { Second Regional } \\
\text { Banks }\end{array}$ & March 1993 & March $1997^{\mathrm{d}}$ & March $1997^{\mathrm{d}}$ & March 1997 \\
\hline Shinkin Banks & $\operatorname{March} 1996^{\mathrm{e}}$ & March 1998 & March 1998 & March 1998 \\
\hline
\end{tabular}

Notes:

a. This table is based on financial statement disclosure requirements. The total amount of bad loan that the entire deposit-taking financial institutions held has been disclosed since September 1995.

b. Voluntary disclosure has existed since September 1995. However, the figures were not included in the official financial statements for that year.

c. The figures have been voluntarily disclosed in annual report since March 1996.

d. The disclosure for March 1996 was voluntary and became required after March 1997. However, all banks actually voluntarily disclosed their figures in March 1996.

e. The National Association of Shinkin Banks recommended disclosure by Shinkin banks with deposits exceeding 100 billion yen. However, compliance was not universal. 
Table 3. The Disclosure Levels of Shinkin Banks by Region

\begin{tabular}{|c|c|c|c|c|c|c|c|c|}
\hline \multicolumn{4}{|c|}{$\begin{array}{l}\text { March } \\
1996\end{array}$} & \multicolumn{5}{|c|}{$\begin{array}{l}\text { March } \\
1997\end{array}$} \\
\hline Area & Nothing & BAD1 & Total & Nothing & BAD1 & BAD1+2 & BAD1+2+3 & Total \\
\hline Hokkaido & 13 & 19 & 32 & 1 & 19 & 0 & 12 & 32 \\
\hline Tohoku & 21 & 18 & 39 & 2 & 15 & 3 & 12 & 35 \\
\hline $\begin{array}{l}\text { Kanto } \\
\text { (excluding } \\
\text { Tokyo) }\end{array}$ & 3 & 47 & 50 & 1 & 39 & 1 & 9 & 50 \\
\hline Tokyo & 12 & 39 & 51 & 7 & 38 & 1 & 1 & 49 \\
\hline Koushinetsu & 3 & 17 & 20 & 1 & 10 & 0 & 9 & 20 \\
\hline Hokuriku & 8 & 17 & 25 & 1 & 4 & 0 & 20 & 25 \\
\hline Tokai & 1 & 46 & 47 & 1 & 20 & 0 & 26 & 47 \\
\hline Kinki & 9 & 44 & 53 & 6 & 32 & 0 & 15 & 53 \\
\hline Chugoku & 18 & 20 & 38 & 2 & 25 & 0 & 7 & 36 \\
\hline Shikoku & 2 & 12 & 14 & 1 & 3 & 0 & 10 & 14 \\
\hline Kyushu & 21 & 26 & 47 & 2 & 25 & 0 & 18 & 46 \\
\hline Total & 111 & 305 & 416 & 24 & 230 & 5 & 139 & 398 \\
\hline
\end{tabular}

Notes: Indicators of disclosure levels are defined as follows: Nothing: No disclosure regarding any kinds of bad loans. BAD1: Only loans to failed companies are disclosed. BAD1+2: Loans to failed companies and loans six month overdue are disclosed. BAD1+2+3: In addition to above two loans, loans whose interest rates are lower than Bank of Japan's discount rates are disclosed. 
Table 4. Disclosure by Failed Shinkin Banks

\begin{tabular}{|c|c|c|c|c|c|c|}
\hline \multirow[t]{2}{*}{$\begin{array}{l}\text { Ex Post } \\
\text { Solvency }\end{array}$} & \multicolumn{2}{|l|}{$\begin{array}{c}\text { March } \\
1996\end{array}$} & \multicolumn{4}{|c|}{$\begin{array}{c}\text { March } \\
1997\end{array}$} \\
\hline & Total & BAD1 & Total & BAD1 & BAD2 & BAD3 \\
\hline & & & & & & \\
\hline Not Failed & 389 & 291 & 371 & 345 & 131 & 126 \\
\hline $\begin{array}{l}\text { Failed in } 1999, \\
2000 \text {, and } 2001\end{array}$ & 14 & 7 & 14 & 10 & 2 & 2 \\
\hline Failed in 2002 & 13 & 8 & 13 & 10 & 2 & 1 \\
\hline & & & & & & \\
\hline Not Failed & 389 & $75 \%$ & 371 & $93 \%$ & $35 \%$ & $34 \%$ \\
\hline $\begin{array}{l}\text { Failed in } 1999 \\
2000 \text {, and } 2001\end{array}$ & 14 & $50 \%$ & 14 & $71 \%$ & $14 \%$ & $14 \%$ \\
\hline Failed in 2002 & 13 & $62 \%$ & 13 & $77 \%$ & $15 \%$ & $8 \%$ \\
\hline
\end{tabular}

Notes: Indicators of disclosure levels are defined as follows: Nothing: No disclosure regarding any kinds of bad loans. BAD1: Only loans to failed companies are disclosed. BAD1+2: Loans to failed companies and loans six month overdue are disclosed. BAD1+2+3: In addition to above two loans, loans whose interest rates are lower than Bank of Japan's discount rates are disclosed. Failure dates are based decision by Deposit Insurance Corporation to inject funds to merging institutions. 
Table 5. Estimation Results for Disclosure Choices

\begin{tabular}{|c|c|c|c|c|c|c|}
\hline \multirow[b]{2}{*}{ Variable } & \multicolumn{2}{|l|}{$\begin{array}{c}\text { March } \\
1996\end{array}$} & \multicolumn{4}{|c|}{$\begin{array}{c}\text { March } \\
1997\end{array}$} \\
\hline & $O L S$ & Probit & $O L S$ & $\begin{array}{c}\text { Ordered } \\
\text { Probit }\end{array}$ & $\begin{array}{c}\text { OLS } \\
\text { Binary } \\
\text { Disclosure }\end{array}$ & $\begin{array}{c}\text { Probit } \\
\text { Binary } \\
\text { Disclosure }\end{array}$ \\
\hline Constant & $\begin{array}{c}-1.908 * * \\
(0.418)\end{array}$ & $\begin{array}{c}-11.758^{* *} \\
(2.015)\end{array}$ & $\begin{array}{c}2.845^{* *} \\
(1.131)\end{array}$ & & $\begin{array}{l}1.102^{* *} \\
(0.525)\end{array}$ & $\begin{array}{c}1.635 \\
(1.611)\end{array}$ \\
\hline LASSET & $\begin{array}{c}0.210^{* *} \\
(0.022)\end{array}$ & $\begin{array}{c}1.045^{* *} \\
(0.129)\end{array}$ & $\begin{array}{c}0.090 \\
(0.059)\end{array}$ & $\begin{array}{c}0.144^{* *} \\
(0.072)\end{array}$ & $\begin{array}{c}0.026 \\
(0.027)\end{array}$ & $\begin{array}{c}0.084 \\
(0.083)\end{array}$ \\
\hline CAPRATIO & $\begin{array}{c}0.002 \\
(0.006)\end{array}$ & $\begin{array}{c}0.001 \\
(0.028)\end{array}$ & $\begin{array}{c}0.044^{* *} \\
(0.018)\end{array}$ & $\begin{array}{c}0.050^{* *} \\
(0.022)\end{array}$ & $\begin{array}{c}0.019^{* *} \\
(0.008)\end{array}$ & $\begin{array}{l}0.045^{*} \\
(0.025)\end{array}$ \\
\hline HATANRATIO & $\begin{array}{c}-2.765 * * \\
(1.249)\end{array}$ & $\begin{array}{c}-10.285^{* *} \\
(5.179)\end{array}$ & $\begin{array}{l}-1.226 \\
(3.501)\end{array}$ & $\begin{array}{l}-0.597 \\
(4.260)\end{array}$ & $\begin{array}{l}-1.108 \\
(1.627)\end{array}$ & $\begin{array}{c}0.293 \\
(5.453)\end{array}$ \\
\hline FURYORATIO & & & $\begin{array}{c}-8.688 * * \\
(2.331)\end{array}$ & $\begin{array}{c}-8.851 * * \\
(2.853)\end{array}$ & $\begin{array}{c}-4.524 * * \\
(1.083)\end{array}$ & $\begin{array}{c}-25.161^{* *} \\
(5.236)\end{array}$ \\
\hline LGDPBRANCH96 & $\begin{array}{c}0.034 \\
(0.085)\end{array}$ & $\begin{array}{c}0.084 \\
(0.375)\end{array}$ & & & & \\
\hline LGDPBRANCH97 & & & $\begin{array}{c}-0.467 * * \\
(0.237)\end{array}$ & $\begin{array}{c}-0.552 * \\
(0.291)\end{array}$ & $\begin{array}{l}-0.208^{*} \\
(0.110)\end{array}$ & $\begin{array}{l}-0.560^{*} \\
(0.340)\end{array}$ \\
\hline \# of observations & 387 & 387 & 382 & 382 & 382 & 382 \\
\hline $\begin{array}{l}\text { Adjusted } \\
\text { R-squared }\end{array}$ & 0.246 & & 0.121 & & 0.139 & \\
\hline $\begin{array}{l}\text { Log likelihood } \\
\text { LR Index (Pseudo } \\
\text { R-squared) }\end{array}$ & -160.603 & -150.215 & -527.081 & $\begin{array}{c}-329.22 \\
0.060\end{array}$ & -234.28 & -215.097 \\
\hline $\begin{array}{l}\text { MacFadden } \\
\text { R-squared }\end{array}$ & & 0.288 & & & & 0.149 \\
\hline$\%$ correct & & 80 & & & & 67 \\
\hline
\end{tabular}

Notes: See text for definitions of qualitative dependent variables. Figures in the parentheses are standard errors. ** Statistically significant at 5\% confidence level. * Statistically significant at $10 \%$ confidence level. 
Table 6. Estimation Results for Disclosure Choices with Regional Failure Dummy

\begin{tabular}{|c|c|c|c|c|c|c|}
\hline \multirow[b]{2}{*}{ Variable } & \multicolumn{2}{|l|}{$\begin{array}{c}\text { March } \\
1996\end{array}$} & \multicolumn{4}{|c|}{$\begin{array}{c}\text { March } \\
1997\end{array}$} \\
\hline & $O L S$ & Probit & $O L S$ & $\begin{array}{c}\text { Ordered } \\
\text { Probit }\end{array}$ & $\begin{array}{c}\text { OLS } \\
\text { Binary } \\
\text { Disclosure }\end{array}$ & $\begin{array}{c}\text { Probit } \\
\text { Binary } \\
\text { Disclosure }\end{array}$ \\
\hline Constant & $\begin{array}{c}-2.146^{* *} \\
(0.456)\end{array}$ & $\begin{array}{c}-12.466^{* *} \\
(2.149)\end{array}$ & $\begin{array}{l}2.151^{*} \\
(1.219)\end{array}$ & & $\begin{array}{c}0.842 \\
(0.567)\end{array}$ & $\begin{array}{c}1.113 \\
(1.684)\end{array}$ \\
\hline LASSET & $\begin{array}{c}0.211 * * \\
(0.022)\end{array}$ & $\begin{array}{l}1.042 * * \\
(0.128)\end{array}$ & $\begin{array}{c}0.096 \\
(0.059)\end{array}$ & $\begin{array}{c}0.152^{* *} \\
(0.073)\end{array}$ & $\begin{array}{c}0.028 \\
(0.027)\end{array}$ & $\begin{array}{c}0.092 \\
(0.084)\end{array}$ \\
\hline CAPRATIO & $\begin{array}{c}0.002 \\
(0.006)\end{array}$ & $\begin{array}{c}0.001 \\
(0.028)\end{array}$ & $\begin{array}{c}0.042^{* *} \\
(0.018)\end{array}$ & $\begin{array}{c}0.049 * * \\
(0.022)\end{array}$ & $\begin{array}{c}0.018^{* *} \\
(0.008)\end{array}$ & $\begin{array}{l}0.045^{*} \\
(0.025)\end{array}$ \\
\hline HATANRATIO & $\begin{array}{c}-2.679 * * \\
(1.250)\end{array}$ & $\begin{array}{c}-10.132 * * \\
(5.168)\end{array}$ & $\begin{array}{c}-0.958 \\
(3.499)\end{array}$ & $\begin{array}{l}-0.267 \\
(4.275)\end{array}$ & $\begin{array}{l}-1.008 \\
(1.628)\end{array}$ & $\begin{array}{c}0.268 \\
(5.464)\end{array}$ \\
\hline FURYORATIO & & & $\begin{array}{c}-8.696^{* *} \\
(2.327)\end{array}$ & $\begin{array}{c}-8.913 * * \\
(2.8861)\end{array}$ & $\begin{array}{c}-4.527 * * \\
(1.083)\end{array}$ & $\begin{array}{c}-24.622 * * \\
(5.254)\end{array}$ \\
\hline LGDPBRANCH96 & $\begin{array}{c}0.080 \\
(0.092)\end{array}$ & $\begin{array}{c}0.236 \\
(0.407)\end{array}$ & & & & \\
\hline LGDPBRANCH97 & & & $\begin{array}{l}-0.337 \\
(0.251)\end{array}$ & $\begin{array}{c}-0.388 \\
(0.310)\end{array}$ & $\begin{array}{l}-0.159 \\
(0.117)\end{array}$ & $\begin{array}{c}-0.471 \\
(0.351)\end{array}$ \\
\hline $\begin{array}{l}\text { REGIONAL } \\
\text { FAILURE }\end{array}$ & $\begin{array}{c}-0.066 \\
(0.052)\end{array}$ & $\begin{array}{c}-0.227 \\
(0.238)\end{array}$ & $\begin{array}{c}-0.203 \\
(0.134)\end{array}$ & $\begin{array}{c}-0.258 \\
(0.163)\end{array}$ & $\begin{array}{c}-0.076 \\
(0.063)\end{array}$ & \\
\hline \# of observations & 387 & 387 & 382 & 382 & 382 & 382 \\
\hline $\begin{array}{l}\text { Adjusted } \\
\text { R-squared }\end{array}$ & 0.247 & & 0.124 & & 0.140 & \\
\hline $\begin{array}{l}\text { Log likelihood } \\
\text { LR Index (Pseudo } \\
\text { R-squared) }\end{array}$ & -159.763 & -149.762 & -525.92 & $\begin{array}{c}-327.974 \\
0.064\end{array}$ & -233.526 & -214.825 \\
\hline $\begin{array}{l}\text { MacFadden } \\
\text { R-squared }\end{array}$ & & 0.290 & & & & 0.151 \\
\hline$\%$ correct & & 80 & & & & 67 \\
\hline
\end{tabular}

Notes: See text for definitions of qualitative dependent variables. Figures in the parentheses are standard errors.

** Statistically significant at $5 \%$ confidence level. * Statistically significant at $10 \%$ confidence level. 


\section{Table 7. Estimation Results for Disclosure Choices with Regional Dummies}

\begin{tabular}{|c|c|c|c|c|c|c|}
\hline \multirow[b]{2}{*}{ Variable } & \multicolumn{2}{|l|}{$\begin{array}{c}\text { March } \\
1996\end{array}$} & \multicolumn{3}{|c|}{$\begin{array}{c}\text { March } \\
1997\end{array}$} & \multirow[b]{2}{*}{$\begin{array}{c}\text { Probit } \\
\text { Binary } \\
\text { Disclosur }\end{array}$} \\
\hline & $O L S$ & Probit & $O L S$ & $\begin{array}{c}\text { Ordered } \\
\text { Probit }\end{array}$ & $\begin{array}{c}\text { OLS } \\
\text { Binary } \\
\text { Disclosure }\end{array}$ & \\
\hline Constant & $\begin{array}{l}-0.998 \\
(0.676)\end{array}$ & $\begin{array}{c}-9.602 * * \\
(3.281)\end{array}$ & $\begin{array}{c}0.442 \\
(1.752)\end{array}$ & & $\begin{array}{l}-0.097 \\
(0.815)\end{array}$ & $\begin{array}{l}-1.103 \\
(2.507)\end{array}$ \\
\hline LASSET & $\begin{array}{c}0.187 * * \\
(0.023)\end{array}$ & $\begin{array}{c}1.052^{* *} \\
(0.141)\end{array}$ & $\begin{array}{c}0.070 \\
(0.062)\end{array}$ & $\begin{array}{c}0.126 \\
(0.078)\end{array}$ & $\begin{array}{c}0.017 \\
(0.029)\end{array}$ & $\begin{array}{c}0.064 \\
(0.090)\end{array}$ \\
\hline CAPRATIO & $\begin{array}{c}0.004 \\
(0.006)\end{array}$ & $\begin{array}{c}0.007 \\
(0.030)\end{array}$ & $\begin{array}{c}0.037^{* *} \\
(0.018)\end{array}$ & $\begin{array}{c}0.045^{* *} \\
(0.023)\end{array}$ & $\begin{array}{l}0.015^{*} \\
(0.008)\end{array}$ & $\begin{array}{c}0.040 \\
(0.026)\end{array}$ \\
\hline HATANRATIO & $\begin{array}{c}-2.601 * * \\
(1.259)\end{array}$ & $\begin{array}{c}-10.254^{*} \\
(5.699)\end{array}$ & $\begin{array}{l}-3.158 \\
(3.528)\end{array}$ & $\begin{array}{l}-2.911 \\
(4.451)\end{array}$ & $\begin{array}{l}-2.097 \\
(1.641)\end{array}$ & $\begin{array}{l}-3.386 \\
(5.764)\end{array}$ \\
\hline FURYORATIO & & & $\begin{array}{c}-6.978^{* *} \\
(2.517)\end{array}$ & $\begin{array}{c}-7.449^{* *} \\
(3.171)\end{array}$ & $\begin{array}{c}-3.636^{* *} \\
(1.171)\end{array}$ & $\begin{array}{c}-22.282^{* *} \\
(5.745)\end{array}$ \\
\hline LGDPBRANCH96 & $\begin{array}{l}-0.074 \\
(0.122)\end{array}$ & $\begin{array}{l}-0.290 \\
(0.576)\end{array}$ & & & & \\
\hline LGDPBRANCH97 & & & $\begin{array}{c}0.007 \\
(0.310)\end{array}$ & $\begin{array}{l}-0.077 \\
(0.394)\end{array}$ & $\begin{array}{c}0.025 \\
(0.144)\end{array}$ & $\begin{array}{l}-0.029 \\
(0.448)\end{array}$ \\
\hline \# of observations & 387 & 387 & 382 & 382 & 382 & 382 \\
\hline $\begin{array}{l}\text { Adjusted } \\
\text { R-squared }\end{array}$ & 0.275 & & 0.162 & & 0.177 & \\
\hline $\begin{array}{l}\text { Log likelihood } \\
\text { LR Index (Pseudo } \\
\text { R-squared) }\end{array}$ & -149.264 & -137.44 & -514.203 & $\begin{array}{c}-317.827 \\
0.093\end{array}$ & -221.891 & -205.923 \\
\hline $\begin{array}{l}\text { MacFadden } \\
\text { R-squared }\end{array}$ & & 0.349 & & & & 0.186 \\
\hline \%correct & & 83 & & & & 72 \\
\hline
\end{tabular}

Notes: See text for definitions of qualitative dependent variables. Figures in the parentheses are standard errors. Specifications included regional dummies, which were not listed for space considerations. The estimations and standard errors of the dummy variables are available upon request. ${ }^{* *}$ Statistically significant at $5 \%$ confidence level. * Statistically significant at $10 \%$ confidence level. 


\section{CESifo Working Paper Series}

(for full list see www.cesifo.de)

1070 Jay Pil Choi, Patent Pools and Cross-Licensing in the Shadow of Patent Litigation, November 2003

1071 Martin Peitz and Patrick Waelbroeck, Piracy of Digital Products: A Critical Review of the Economics Literature, November 2003

1072 George Economides, Jim Malley, Apostolis Philippopoulos, and Ulrich Woitek, Electoral Uncertainty, Fiscal Policies \& Growth: Theory and Evidence from Germany, the UK and the US, November 2003

1073 Robert S. Chirinko and Julie Ann Elston, Finance, Control, and Profitability: The Influence of German Banks, November 2003

1074 Wolfgang Eggert and Martin Kolmar, The Taxation of Financial Capital under Asymmetric Information and the Tax-Competition Paradox, November 2003

1075 Amihai Glazer, Vesa Kanniainen, and Panu Poutvaara, Income Taxes, Property Values, and Migration, November 2003

1076 Jonas Agell, Why are Small Firms Different? Managers’ Views, November 2003

1077 Rafael Lalive, Social Interactions in Unemployment, November 2003

1078 Jean Pisani-Ferry, The Surprising French Employment Performance: What Lessons?, November 2003

1079 Josef Falkinger, Attention, Economies, November 2003

1080 Andreas Haufler and Michael Pflüger, Market Structure and the Taxation of International Trade, November 2003

1081 Jonas Agell and Helge Bennmarker, Endogenous Wage Rigidity, November 2003

1082 Fwu-Ranq Chang, On the Elasticities of Harvesting Rules, November 2003

1083 Lars P. Feld and Gebhard Kirchgässner, The Role of Direct Democracy in the European Union, November 2003

1084 Helge Berger, Jakob de Haan and Robert Inklaar, Restructuring the ECB, November 2003

1085 Lorenzo Forni and Raffaela Giordano, Employment in the Public Sector, November 2003 
1086 Ann-Sofie Kolm and Birthe Larsen, Wages, Unemployment, and the Underground Economy, November 2003

1087 Lars P. Feld, Gebhard Kirchgässner, and Christoph A. Schaltegger, Decentralized Taxation and the Size of Government: Evidence from Swiss State and Local Governments, November 2003

1088 Arno Riedl and Frans van Winden, Input Versus Output Taxation in an Experimental International Economy, November 2003

1089 Nikolas Müller-Plantenberg, Japan’s Imbalance of Payments, November 2003

1090 Jan K. Brueckner, Transport Subsidies, System Choice, and Urban Sprawl, November 2003

1091 Herwig Immervoll and Cathal O'Donoghue, Employment Transitions in 13 European Countries. Levels, Distributions and Determining Factors of Net Replacement Rates, November 2003

1092 Nabil I. Al-Najjar, Luca Anderlini \& Leonardo Felli, Undescribable Events, November 2003

1093 Jakob de Haan, Helge Berger and David-Jan Jansen, The End of the Stability and Growth Pact?, December 2003

1094 Christian Keuschnigg and Soren Bo Nielsen, Taxes and Venture Capital Support, December 2003

1095 Josse Delfgaauw and Robert Dur, From Public Monopsony to Competitive Market. More Efficiency but Higher Prices, December 2003

1096 Clemens Fuest and Thomas Hemmelgarn, Corporate Tax Policy, Foreign Firm Ownership and Thin Capitalization, December 2003

1097 Laszlo Goerke, Tax Progressivity and Tax Evasion, December 2003

1098 Luis H. B. Braido, Insurance and Incentives in Sharecropping, December 2003

1099 Josse Delfgaauw and Robert Dur, Signaling and Screening of Workers' Motivation, December 2003

1100 Ilko Naaborg, Bert Scholtens, Jakob de Haan, Hanneke Bol and Ralph de Haas, How Important are Foreign Banks in the Financial Development of European Transition Countries?, December 2003

1101 Lawrence M. Kahn, Sports League Expansion and Economic Efficiency: Monopoly Can Enhance Consumer Welfare, December 2003

1102 Laszlo Goerke and Wolfgang Eggert, Fiscal Policy, Economic Integration and Unemployment, December 2003 
1103 Nzinga Broussard, Ralph Chami and Gregory D. Hess, (Why) Do Self-Employed Parents Have More Children?, December 2003

1104 Christian Schultz, Information, Polarization and Delegation in Democracy, December 2003

1105 Daniel Haile, Abdolkarim Sadrieh and Harrie A. A. Verbon, Self-Serving Dictators and Economic Growth, December 2003

1106 Panu Poutvaara and Tuomas Takalo, Candidate Quality, December 2003

1107 Peter Friedrich, Joanna Gwiazda and Chang Woon Nam, Development of Local Public Finance in Europe, December 2003

1108 Silke Uebelmesser, Harmonisation of Old-Age Security Within the European Union, December 2003

1109 Stephen Nickell, Employment and Taxes, December 2003

1110 Stephan Sauer and Jan-Egbert Sturm, Using Taylor Rules to Understand ECB Monetary Policy, December 2003

1111 Sascha O. Becker and Mathias Hoffmann, Intra-and International Risk-Sharing in the Short Run and the Long Run, December 2003

1112 George W. Evans and Seppo Honkapohja, The E-Correspondence Principle, January 2004

1113 Volker Nitsch, Have a Break, Have a ... National Currency: When Do Monetary Unions Fall Apart?, January 2004

1114 Panu Poutvaara, Educating Europe, January 2004

1115 Torsten Persson, Gerard Roland, and Guido Tabellini, How Do Electoral Rules Shape Party Structures, Government Coalitions, and Economic Policies? January 2004

1116 Florian Baumann, Volker Meier, and Martin Werding, Transferable Ageing Provisions in Individual Health Insurance Contracts, January 2004

1117 Gianmarco I.P. Ottaviano and Giovanni Peri, The Economic Value of Cultural Diversity: Evidence from US Cities, January 2004

1118 Thorvaldur Gylfason, Monetary and Fiscal Management, Finance, and Growth, January 2004

1119 Hans Degryse and Steven Ongena, The Impact of Competition on Bank Orientation and Specialization, January 2004

1120 Piotr Wdowinski, Determinants of Country Beta Risk in Poland, January 2004 
1121 Margarita Katsimi and Thomas Moutos, Inequality and Redistribution via the Public Provision of Private Goods, January 2004

1122 Martin Peitz and Patrick Waelbroeck, The Effect of Internet Piracy on CD Sales: CrossSection Evidence, January 2004

1123 Ansgar Belke and Friedrich Schneider, Privatization in Austria: Some Theoretical Reasons and First Results About the Privatization Proceeds, January 2004

1124 Chang Woon Nam and Doina Maria Radulescu, Does Debt Maturity Matter for Investment Decisions?, February 2004

1125 Tomer Blumkin and Efraim Sadka, Minimum Wage with Optimal Income Taxation, February 2004

1126 David Parker, The UK's Privatisation Experiment: The Passage of Time Permits a Sober Assessment, February 2004

1127 Henrik Christoffersen and Martin Paldam, Privatization in Denmark, 1980-2002, February 2004

1128 Gregory S. Amacher, Erkki Koskela and Markku Ollikainen, Deforestation, Production Intensity and Land Use under Insecure Property Rights, February 2004

1129 Yin-Wong Cheung, Javier Gardeazabal, and Jesús Vázquez, Exchange Rate Dynamics: Where is the Saddle Path?, February 2004

1130 Alberto Alesina and Guido Tabellini, Bureaucrats or Politicians?, February 2004

1131 Gregory S. Amacher, Erkki Koskela, and Markku Ollikainen, Socially Optimal Royalty Design and Illegal Logging under Alternative Penalty Schemes, February 2004

1132 David M. Newbery, Privatising Network Industries, February 2004

1133 Charles Yuji Horioka, The Stagnation of Household Consumption in Japan, February 2004

1134 Eiji Fujii, Exchange Rate Pass-Through in the Deflationary Japan: How Effective is the Yen's Depreciation for Fighting Deflation?, February 2004

1135 Mark M. Spiegel and Nobuyoshi Yamori, Determinants of Voluntary Bank Disclosure: Evidence from Japanese Shinkin Banks, Febrary 2004 